\title{
THE DESTINAL QUESTION OF LANGUAGE
}

\author{
Saitya Brata Das* \\ satyadx@yahoo.com
}

\begin{abstract}
How can we think the destinal place of language in the essentially historical condition of our existence if such historicity cannot be understood on the basis of the labor of negativity alone? The attempt is made here to think language in a more originary manner, as non-negative finitude, that affirms what is outside dialectical-speculative closure, what is to come. The notion of 'destinal' itself is thus transformed. No longer being merely a categorical grasp of "entities presently given", language is an originary exposure to the event of arrival in its lightning flash. Destiny appears as that of the messianic arrival of the 'not yet' which is not a telos that the immanent movement of historical reason reaches by an irresistible force of the negative. This essay reads Schelling, Heidegger and Kierkegaard to think language as a "place" of exposure to the non-teleological destiny that may erupt even today, here and now, without any given conditionality.
\end{abstract}

Keywords Continental philosophy, language, mortality, messianic

RESUMO Como nós podemos pensar o lugar destinal da linguagem na condição essencialmente histórica de nossa existência se tal historicidade não pode ser entendida com base apenas no trabalho da negatividade? Fazse aqui a tentativa de pensar a linguagem de um modo mais originário, como finitude não negativa, que afirma o que se encontra fora do fechamento dialético-especulativo, o que está por vir. A própria noção de 'destinal' é então transformada. Não sendo mais apenas uma apreensão categorial de

* Professor na Sri Venkateswara College - Delhi University e membro do Indian Institute of Advanced Study. Artigo recebido em 7/07/2010 e aprovado em 26/01/2011.

KRITERION, Belo Horizonte, nº 123, Jun./2011, p. 121-138. 
"entidades presentemente dadas", a linguagem é uma exposição originária ao evento da chegada em seu instante iluminador. O destino aparece como o da chegada messiânica do 'ainda não' que não é um telos que o movimento imanente da razão histórica atinge por meio de uma irresistivel força do negativo. Este ensaio lê Schelling, Heidegger e Kierkegaard para pensar a linguagem como um "lugar" de exposição ao destino não teológico que pode irromper mesmo hoje, aqui e agora, sem nenhuma condicionalidade dada.

Palavras-chave Filosofia continental, linguagem, mortalidade, messiânico

\section{The Event of Language}

A dominant onto-theological metaphysics of the West presumes to begin without any pre-suppositional ground. For such metaphysics, the question of existence in its essential and irreducible mortality cannot be a fundamental question. Therefore, such an onto-theological metaphysics does not begin with the question of existence, for in that manner it must already begin with a pre-supposition: the "the- there" of existence. Instead it must begin with the pure essence of 'Being' which is immediate and indeterminate, since nothing is pre-supposed in this pure, empty, universal concept called: 'Being'. Thus begins Hegel's systematic speculative logic, with pure Being, empty and universal, and therefore is without pre-supposition. On the other hand, we shall begin with a pres-supposition, with the "the-there" of existence which is essentially finite and irreducibly mortal. An essential thinking that does not make mortality the end result of a dialectical-historical process begins with mortality as presupposition, or as the starting point. Only that way philosophical thinking keeps open the way of thinking to the coming time, time that survives death, remains after death. The way opens itself to time that is to arrive. The way is not 'way' if it is to end with death, or if it makes death its end. The way, then, if does not have to end its 'way' character, has to make death as the point of departure rather than as the end point. That is why the way of thinking makes death itself as the starting point, not an end. It addresses death as question, or better, death addresses us as question, question that seizes us with the tremor of mortality, fascinates and astonishes us and touches us as destiny. The question why mortality seizes us as the question of destiny is the destinal question of language. Language does not make death the end result of a speculative process and that is why language holds us 
essentially in its promise, the promise of language that is at once the promise of time yet to come. Only he who hears this promise, to whom this promise is granted first of all, one who is finite and mortal, is open thereby what the way opens towards, that is - to the coming time, to the affirmation of the pure future. It will be illuminating here to discuss the later Heidegger's thinking of language. Heidegger here attempts to think the promise of language which is essentially that of thinking the way, thinking on the way, thinking underway which is going under, thinking on the way to thinking, for the way grants to mortals in advance, it gives (es gibt) already - the advent, the coming to presence, but not what has presently come as this or that coming amenable to the categorical, intelligible gaze of the knower. Thinking on the way is the very promise of thinking that arrives in advance, before anything else , as immemorial and that is why it also appears as destinal. What gives in advance is called 'inception' (Anfang), which is distinguished by Heidegger from 'beginning' (Beginn). In his 1934-35 lectures on Hölderlin's hymns "Germanien" and "Der Rhein", Heidegger says,

\begin{abstract}
'Beginn' - das ist etwas anderes als 'Anfang'. Eine neue Wetterlage, z. B. beginnt mit einem Sturm, ihr anfang aber ist die vorauswirkende, völlige Umwandlung der Luftverhältnisse. Beginn ist jenes, womit etwas anhebt, Anfang das, woraus etwas enspringt. Der Weltkrieg fing an vor Jahrhunderten in der geistig-politishen Geschichte des Abenlandes. Der Weltkrieg begann Vorpostengefechten. Der Beginn wird alsbald zurückgelassen, er verschwindet im Fortgang des Geschehens. Der Anfang, der Ursprung, kommt dagagen im Geschehen allererst zum Vorschein und ist voll da erst an seinem Ende ${ }^{1}$ (Heidegger 1980, p.3).
\end{abstract}

In another lecture on language that are collected as On the Way to Language, Heidegger says of the promise of this advent, of this inception, thus: "For man is man only because he is granted the promise of language, because he is needful to language, that he may speak it"'( Heidegger 1982, p.90). This 'already' the-there of promise that is granted to man in advance so that he may speak a language: how to think this 'in advance', which is not a being among beings, an entity among entities and that is given to man in a more originary manner than anything 'presently given'? Not anything

1 I have translated this paragraph as follows: “'Begin' - that is something else than 'Inception'. A new weather condition, for example, begins with a storm; its inception is ,however, is the transformation in advance, the complete transformation of air conditions. Beginning is each time with which something arises; inception that, from which something erupts (springs forth). The world war incepted on centuries ago in the spiritual-political history of the West. The world war began proponed positioning. The beginning is left immediately; it disappears in the continuation of the happening. The inception, the origin, comes to appearance as fore-shining and is fully there first of all only at its end". 
('presently given') nor pure and simple nothingness of negativity with which Hegel's Logic begins: how to think this the-there of the promise, or the gift of language if not as an essential, originary finitude, which already in advance grants the mortals the promise of language? The task of thinking that seeks to hearken to this promise of language begins with the question of finitude and mortality, which is to be understood here in its non-negative finitude. The pain of this finitude that adheres to language is thus not the pain of the labor of the negative. To begin with death is not to make death a cognitive entity so as to ground the speculative historical process of a philosophical thinking. It is rather otherwise. If it is from language alone that we experience death as death, and that this language of man is already always seized by the tremor of mortality, then mortality is precisely the non-condition, the unground that keeps the historical world open, like an open wound, to what is forever outside of what has come as unground, or as the-there. The event of language arrives as un-grounded clearing, or, as the un-ground of a clearing, whose occurring is singular each time, and thus irreducible to the universality and general order of the conceptual cognition. The ecstatic occurrence of this event of language is not one being among beings, not one category among categories, but is originary opening, is the more primordial disclosure to what is not yet given.

In the very beginning of his Being and Time (1962) Heidegger distinguishes existential in its originary apophantic dimension of language from the categorical grasp of 'presently given' (Vorhandenheit) entities. What Heidegger there refers to as 'da' of Dasein, as the there, the facticity of Dasein - Dasein whose being is being-towards-death - is also thereby essentially, in the innermost manner, a linguistic existence whose existentiality is this being-towards-death. Dasein is that existence whose 'da' lies in the originary apophansis of language, even before language comes to be categorical and predicative of 'presently given entities'. In section B of 97 that belongs to the Introduction II of Being and Time, Heidegger attempts to understand the concept of Logos in a more originary manner than as mere locus of logical truth. Logos is thus understood here as originary disclosure of this existentiality of existence called Dasein whose existentiality is this 'beingtowards-death'. It is this intimate connection between the logos of language with the logos of mortality that precisely makes first of all Dasein as existence irreducible to the entities 'presently given', this event of language irreducible to the truth of logic in its propositional, predicative structure. Therefore the task of Destruktion der Ontologie ( as one of the two fold tasks of Being and Time) accompanies the 'destruction' of traditional logic in its propositionalpredicative structure in order to reveal, in retrogressive manner, the buried, 
originary pre-supposition, which is, the existentiality of a linguistic existence as being-towards-death. The existence whose existentiality is this 'towardness', this ahead-ness (understood in the infinitude of the verbal resonance of 'to') towards its own impossibility, to its own nothingness and abyss and in so far as this toward-ness to death first of all discloses itself in the originary existential-apophansis of language - existence is therefore already always attuned to language, essentially, and in the innermost manner. What Heidegger here attempts to think in the name 'logos' to which mortals in their being-towards-death are attuned to, and yet which can not be appropriated by these mortals, is not 'reason' of 'human' as against the sheer brutal, instinctive assertion of brute being-among-beings, but the originary apophansis before the categorical grasp, that lies even before what Husserl refers to as "categorical intuition". Language is thus not primarily the predicative locus of "truth' as the truth of what has appeared, but enabling-clearing, disclosing-appearing of the unapparent, which is without name and without concept, which in the midst of existing opens from the very heart of existence like an yawning abyss, which seizes those mortals who speak with fear and trembling. Language then, if I am allowed to say this, is the site of this unapparent apparition, which is the event of existence that is prior to the entities "presently given". It is as if the event of language is each time born out of an abyss that remains outside us like an eternal remainder of non-knowledge, the abyss where language ruins itself while incessantly, interminably moving towards it as if towards its own essence, that means, towards its outside. Language of this linguistic existence is this being-towards its own ruination on the basis of which the unapparent apparition takes places, erupts in the midst of very existing.

The event of language is this event of existence itself whose existentiality lies in its very toward-ness to its un-working-ruination where the intensity of the moment of ripeness is at once its dissolution and sinking unto nothing without being converted into being, as if language in its very ripeness and plenitude coincides with its own dissolution. The simultaneity of the ripeness and its ruination, fullness and dissolution, arises like lightning which language in its inability to contain itself, at once points to, indicates to what is outside all representation, rendering the outside as wholly otherwise manifestation, the unapparent, the bluish evaporating of death. Death thus at once makes manifestation possible, while ruining the very works of any figuration. The intensity of the moment is this dis-figuring expropriation of language from

2 For Heidegger's critique of Husserl's notion of “categorical intuition” , I refer to Heidegger's seminars in Le Thor ( Heidegger 2003). 
its own gathering, rendering language to say the unsayable and to unsay the sayable, to point towards at once, simultaneously, what language is and what language is not. Language is this strange monstrous site where - as Kierkegaard says ${ }^{3}$, opposing Epicurus - where death is, I am as this linguistic being is there; in other words, which is to say, ' I am there where I am not there', where this simultaneity of ' where I am' and 'where I am not' is without reconciliation, without synthesis . Language presents this simultaneity of the disjoining - 'of 'where I am' and 'I am not' - this discontinuous continuity, or continuous discontinuity as dieresis where non-being intensifies itself more being insists in itself, like an infinite debt where the debt increases itself more we pay off, as a result there never occurs the instant when the debt and pay off is leveled off, when 'being and nothing is the same'.

Unlike Hegel's speculative-logical determination of beginning, language neither begins with the identity of being and nothing, nor ends it there. This instant when the being and nothing is the same can happen only in logical system where nothing really happens at all in so far as all happening here is merely a logical movement but not the event of existence. The event of existence begins, because of its inextricable finitude and mortality, as indebted, as - what Schelling (1936) calls - 'loan'. This infinite loan is the presupposition of an 'already there', 'the-there' as facticity of existence, an immemorial, infinite past. This facticity and presupposition of language with which the event of existence begins is, unlike Hegel's system of logic, for Hegel's logical system does not need presupposition in order to constitute itself as system. This presupposition of the event of language, which is also the event of existence, is nothing but this mortality itself which Hegel's system has to exclude in order to be an all inclusive system, as All. It is because of this exclusion Hegel's all inclusive system remains outside language, and outside existence, for the event of language is essentially pre-suppositional, i.e., it presupposes not what is "presently given", but the inapparent that strikes language with its lighting flash. In so far as each discourse is finite, the structural opening of each discourse begins as gratitude, as thankfulness for its coming into existence, for the gift of its existence which is never paid off. In so far as this gratitude is never leveled off with the finitude of this existence, in so far as more the infinitude increases more finitude of existence expands itself, transcends itself, ecstatically goes beyond itself, the moment in 
existence itself is never reached when existence is equal to what it is indebted to, to what is its presupposition, to what is the very condition of its possibility.

Language is never equal to its own presupposition, never equal to itself, is never equal to - how to say this? - its own nothing, its own finitude, its own limit and its own mortality that in a manner of unapparation, gives to language its open-ness to its own arrival. The event of language whose existentiality is this being-towards-its-own-nothing never can appropriate this 'toward-ness' simply because this 'toward-ness' is its very presupposition to which it never attains, from which it already always falls off, more exuberantly it moves towards this 'toward-ness', more ecstatic is this movement, more and more it affirms itself. Language in this eventive character is, thus, paradoxically, an infinite impoverishment and infinite plenitude at once that forever draws it out of its limit and exposes it to the pure advent of the inapparent.

The movement of language is this moving towards its own essence, its fulfillment as language, its happiness and its plenitude that is also its very ruination. This aporia of language - its dieresis - is never sublated into speculative reconciliation of the synthesis; rather, synthesis here is excluded as excluded synthesis, of what Rosenzweig calls 'an excluding All'( Rosenzweig $2005,19)$. The event of thinking that begins with language, therefore, begins with presupposition, which is this radical finitude, this mortality of language, and its indebt-ness to what is outside thinkable and outside system, namely, the inapparent advent of language itself coming into presence, beyond all the visible, apparent forms of "the presently given entities". Franz Rosenzweig's The Star of Redemption thus begins with this question of presupposition. It begins with the interrogation of that claim which the system as philosophy of All makes on behalf of thinkable that it does not presuppose anything. This claim - that it is presupposition-less - is the very presuppositional condition of the possibility of the system at all, the presupposition that death is nothing, or rather that death must be thinkable, if at all there be anything like thinkable. What makes thinkable alone 'thinkable' is the presupposition that it is presupposition-less; this alone makes, by reducing the inapparent character of the pure arrival of the language into apparent, visible forms of the "categorical intuition", the system of knowledge, of light and of its ontological intelligibility. Therefore death is nothing in the philosophy of All. It has to cast aside death's "poisonous sting" and "its pestilential breath", the fear and trembling which is heard in each mortal cries in the face of death. That this philosophy of All has to deny the presupposition of the event of existence - existential facticity that the nothing of death is something - this philosophy also has to be thereby bereft of language. The presupposition of the 
event of language is the unthinkability of death, but an unthinkability which is for that matter not pure nothing but something, a mortal "pitiless cry", from where thinking begins, from where language erupts - with a nothing that is something. Rosenzweig then says:

But when philosophy denies the dark presupposition of all life, when it does not value death as something, but makes it into nothing, it gives itself that appearance of having no presupposition. In fact, all cognition of the All has for its presupposition - nothing. For the one and universal cognition of the All, only the one and universal nothing is valid. If philosophy did not want to stop its ears before the cry of frightened humanity, it would have to take the following as its point of departure and consciously as its point of departure - : the nothing of death is a something, each renewed nothing of death is a new something that frightens anew, and that can not be passed over in silence, nor be silenced. (Ibid., p.11).

What can not be included therefore within the universal representation of philosophy as the cognition of the All is this facticity of the nothing that is something, this unthinkable presupposition of the event of existence, this presuppositional opening that each time enables language to erupt and ruin itself. It is with this presupposition that, like Rosenzweig's text, that we shall begin here. It is this presuppositional opening that discloses existence its own finitude, its inextricable, indescribable, unthinkable mortality that ties existence to its own condition of possibility and impossibility at the same time, so that one who exists has to say - if he is not duping himself in the deception of a philosophical promise - that when one is, one is not. When one says, each time one says, as Kierkegaard - 'when I am, I am not' - this saying occurs, erupts each time with such fear and trembling, with such stammering, with such anguish and tremor chocking one's throat, which must be the very throat of language. The anguish of language lies in its presuppositional structure in the face of the unthinkable advent of the inapparition, which is outside the presupposition-less, harmless, sterile cognition of the thinkable. The real event of thinking begins here, with its dark presupposition, with the anguish and terror of language that means, with the un-thinkable, with - what Schelling (2000) calls - the "un-pre-thinkable" (Unvordenkliche), with the actuality before mere potentiality of concepts, with the facticity of the Abgrund which precedes all grounding. Such a mortal thinking does not begin with the presupposition-less concepts, with the thinkable of the potential, with harmless, sterile cognition bereft of language, but with the dark presupposition, with the abyss of a facticity where all thinkable falls silent, from where language erupts disclosing the unapparent. It is this event of language from which alone we know death as death, where the manifestation of the unapparent arrives 
in lighting flash, opening this abyss at the very heart of all thinkability, of all explication, of all interpretation, of all grounding acts of reason.

A mortal thinking that begins with its dark presupposition, with the anguish and terror in the face of pitiless death, has therefore to be a language-thinking, not language as mere medium of spirit, as mere means of communication at the cognitive disposal of the categorical apparatus, but a thinking that is essentially linguistic in its inextricable presupposition. As death is sought to be domesticated in the system of visible forms, so language is reduced to its categorical function of grasping apparent, visible entities "presently given" at its cognitive disposal. What is not domesticated is the presuppositional, structural opening moment of language: the pitiless cries of the irreducibly singular mortals in the face of death that demands of a redemptive arrival which language in its cognitive disposal can not predicate, and can not make it a part of its programmatic projection of being. Such a thought runs throughout Emmanuel Levinas' (see for example, Levinas 2000) works. Death cannot be reduced to any programmatic projection of being, insofar as death is not mere nothingness but the unknown and hence is irreducible to any ontological mastery or thematization. In his early work Time and the Other, Levinas speaks, "The end of mastery indicates that we have assumed existing in such a way that an event can happen to us that we no longer assume, not even in the way we assume events - because we are always immersed in the empirical world - through vision. An event happens to us without our having absolutely anything "a priori", without our being able to have the least project, as one says today. Death is the impossibility of having a project (Levinas 1987, p. 74).

This language does not primarily belong, without remainder, to the world of negativity constituted by the work of synthesis, nor is language primordially in the cognitive function of the speculative-historical judgment. By not completely belonging to the dialectical-historical closure, language opens itself to the non-conditional promise of the inception that is outside synthesis, outside the reconciliatory pathos of dialectical history. What is bestowed by language upon man as gift opens in this abyss, which is the Open, not the ontological nor topological site, but the very monstrous site where the inapparent event arrives incalculably. Language is thus to be more originary understood than mere locus of predicative, propositional truth, but as announcing or heralding what is coming to come, presencing to presence. It is in this sense the early Heidegger too attempted to understand the meaning of "hermeneutic" in conjunction with language beyond its predicative, categorical function (Heidegger 1999): the inextricably linguistic mortal being 
is that who is abandoned to the open space where Being itself advents. This advent of Being strikes the language that welcomes, announces - because it is already always disclosed open to the event, is enowned (appropriated) to the event - its inapparent presencing to presence. Only in so far as the gift originates as if from an abyss, that there can be something like gift, that there is gift for the one who himself is marked by death, has his ground like an abyss that is outside his mastery, outside his power. This gift is the gift of language.

\section{Death, Time and Techne}

A categorical language entirely at the service of cognitive disposal is a language bereft of language, for such a categorical language is either mere means, or an instrumental function at the service of technological calculability and manipulation where the disclosive coming into presence is 'entrapped' in En-Framing (Gestalt), or it becomes a mere medium of the self-appearing of the metaphysics of the Subject: in both ways language does not appear as language but appears in the apparatus of "technological cold" (Bloch 2000), in the regime of knowledge-production, as metaphysical categories. In both ways language in the flash of its lightning that seizes the mortals is leveled off to the homogeneity of the already circulated signification, where each moment that ecstatically, exuberantly affirms the future is leveled off to what Benjamin calls "homogenous empty time"(Benjamin 1977, pp. 251-61). Time of this categorical signification at the cognitive disposal that makes its appearance within a certain apparatus of 'truth' - in its calculative, technological manipulability -is the time where the intensity of the exuberant, messianic moment is reduced, leveled off to the cold, harmless, barren succession of instants infinitely lengthening itself as ever same infinite. Time of this signification at the age of technical calculability is the time of boredom: infinite lengthening of the same and as infinite lengthening of the same, such a time encounters neither the fulfillment of future nor the immemorial promise of past that is the excess of the totality of the average presently present 'nows'. In other words, this time does not know the messianic happiness of the pure future which never arrives in the present 'now', for the temporality of the event is never that of the 'now' that is illuminated by the light of the categorical intuition. The sense of eternity that this eternal lengthening of 'now' instant gives, is a false eternity. Despite its eternal lengthening of time - which is an eternity of boredom, or a boring eternity - it is enclosed in the solipsism of its self-presence, in the immanence of its self-consuming 'nows', i. e., it does not know the true transcendence. Only a false assumption of transcendence, 
it is only the self-generating movement of the same, for it bears its movement from itself alone, an autochthonous product, without any relation to happiness or to surprise of the event that arrives as surprise that draws being outside its boredom, and gives over to the ecstasy of welcoming the other yet to come.

Therefore signification that is the product - and this productive nature of signification is to be underlined here - of the apparatus appears to be a-temporal, or as eternity, as a kind of autonomous-autochthonous machine generation, production of signification that is like what Heidegger calls 'idle chatter' of the They (das Man), the faceless, anonymous gossip that circulates and thereby infinitely re-generates itself and thus constantly evades from the facticity of language, from the existence's presuppositional structure, as if there is no such thing called 'death'. The time of eternal boredom is the time of prattle, the time of eternal circulation of the ever same rumor in its rumorcharacter of the das Man, of the one who has been denuded of his face, as if time itself here - in its non-encounter with death - has lost its face. Or rather the time of eternity which boredom gives to rumor, precisely in its evasion of death, is an interminable dying, an eternal murmuring, an incessant monotony that is, precisely thereby, enclosed within the immanence of self-enclosed solitude of the imprisoned self without exits. Like the endless noises of the machines without subjectivity (whose essence would be its transcendence), an existent thrown into boredom does not know the event of language. At the age of technological reproduction, time of this monotony is bereft of language that constantly reproduces its own apparatus of truth as normative truth. This normative truth is anonymous, faceless, incessant lengthening of time: it assumes everyone's face without assuming anyone's face. Like the supposedly eternal validity of law whose time is the interminable, anonymous lengthening of 'now' instant, and like the eternally young and eternally old gossip, the truth of the technological modernity assumes everyone's face and no one's face. Law is like gossip to a great extent: through its very anonymity, the cunning of law allows itself to pass as categorical truth and assumes a false universality without singularity, a normative state of exception as rule where exception never ceases to function as rule and yet claiming itself to be the exception. All this pass out, deceptively, in the name of an open liberality, and supposed equality that is accomplished by a liberal democratic process that has tied out its process of emergence with the "technological cold". Time of this gossip is thus a time of an anonymous universality that is entirely false universality because it does not know the surprise of the singular advent, which is the true exception and true universal ; being bereft of its singularity and its eruption character, such a time of eternal present assumes, in the 
contemporary juridico-political determination of democracy, an immanent politics of self-consuming predicates that never ceases to reproduce, in the name of event, "events" without surprise. Time, however, has not here lost its face. It rather never ceases to assume a face of the event, which is actually the face of the old spinster in a fairy tale, who endlessly moves the wheel of time, who endlessly keeps drawing into the immanence of self-presence only what is already passed by. It is a time, borrowing Heidegger we shall say, which is vulgar time, a time that has taken away "death's poisonous sting" (Rosenzweig 2005,p. 9), time that has diseased the event of language, and yet make it appear as if it is eternal, deathless, or worse, democratic, liberal, humanist.

What the age of technological cold promises, in its calculable reduction of the event and mastery of true exception, is a promise of immortality. In this sense the technological calculability - as Heidegger very brilliantly notices this essence of technology - is nothing technical but metaphysical in its nihilistic character, in its thana-ontolgical character. In its determination to master death, the nihilistic thanatological essence of technology subsumes death only by taking 'death's poisonous sting" (Ibid), or "death's decision" (Kierkegaard 1993, pp. 71-102). In itself, the gossip of technology evades "death's earnestness" (Ibid) by reducing "death's decision" into mere homogenous, empty instants of technological production. Death then becomes a work at the service of an eternally monotonous process of negativity and boredom, without hope and without surprise; death then becomes product, an anonymous product where each death is like everyone's death, and like no one's death; death, then, becomes a normative state of exception, like the works of law that continually maintain its violence by summoning "each one" as "every one" to juridico-legal judgment ( but evading justice), where "each one", becoming "everyone" thereby becomes "no one", where each one is robbed of his face because he encounter's his death nowhere in its "decision" but encounters the incessant murmur of an eternal dying where no one really dies, in so far this no one is the everyone, the They. This death then, at the endless accomplishment of technological mastery, becomes production in a factory, a capital for neo-liberal democracy. Death then appears, like gossip and rumor, as pure banality, as banal and as abstract a death like - what Hegel speaks of a certain death - "swallowing the mouthful of water". This boredom, this banality, this cold and monotony of the machine-age is like the eternally homogenous time when each is allowed to die freely, of his or her own accord - like its homogenous instants that monotonously come and pass away in a banal succession - only in so far as this death has already become no 
one's death, as if no one is free to die anymore. What the "technological cold" seeks, in this way, through this leveling off of moments, and stretching into a banal infinity, is to capture, arrest, master, domesticate that moment which is the instant of death that inscribes itself between anything like natural given and product, between nature and history. Death then becomes an inscription of time, and language is reduced to a mere medium, as mere service provider as this inscription, as this draft, as this typography. When language is reduced into a mere functional value as inscription, then its event character is abandoned. Then there arises the necessity to abandon this abandonment in order to open language to its event character once more, so that language once more arrives as pure arriving, as 'to come'.

Therefore affirmation of the event-character of language demands that it to take a negative form in the name of a higher affirmation without its theticpositing. The contemporary researches and studies of language that seek to formalize language in terms of its syntactic, structural, or phonological character, do not abandon this inscription-character, and therefore they already foreclose, in their very conceptual delimitation and methodological presuppositions, the event-character of language as such, even in anything like generative grammar which can formalize what is generated. Therefore modern linguistics and much of cognitive linguistics are metaphysical thorough and thorough; they are the draft, or inscription of death where technological man seeks to recognize his own face.

Walter Benjamin in his beautiful text called Language as Such and Language of Man recognizes a touch of melancholy at this (mis)recognition of man when man seeks to recognize his own face - which is the birth of history for man - as the melancholy of the overnaming, when language becomes for him mere medium of communication, mere medium of man's assertion of his power to name, in other words, when name becomes overnaming, namely, the language of judgment. As if language itself suffers here by being reduced to inscription, to that draft at the cognitive disposal, where death, instead of being that originary finitude which is gift of the creaturely existence, becomes - in the overnaming - prattle. Thus Benjamin calls the ceaseless overnaming that has already lost the gift-character of language given with the paradisiacal Naming of proper names, as prattle. Therefore the categorical language is bereft of the character of proper name, for the proper name appears as gift from the wholly other to the one who is singular, irreducible and who as the irreducible one, is summoned forth by the gift of this name to face the sign of mortality that language, in its irreducibility to propositions and predications, points towards, in the hint of its showing. 
Taking this clue from Benjamin, we can go forth to say that the proper name, therefore, is borne out of the encounter with the singular, inescapable, inextricable death as death, and out of this encounter with this death, to be responsible to the others who are mortals. The proper name is far from property or propriety of the one who bears the proper name; he can neither appropriate his own name nor can he bear it like property of his self-identity. $\mathrm{He}$ is already always dispropriated from anything like self-identity by virtue of being endowed with a proper name, for he is already always responsible to the other ( from where language immemorially arrives to him as gift) - who is yet to come - a responsibility that has already always occurred to him, a responsibility that is presupposed in being endowed with a proper name.

To be endowed with a proper name is not being able to be oneself, a solitary and selfenclosed, autochthonous entity; it is rather to encounter, on the basis of an originary dispropriation, the other mortals to whom one is responsible and to other time, when the time of the meaning of the address is the not yet. It is to introduce temporality into discourse, the time of an infinite future at the very heart of finitude so that the address to the others, in its infinitude, appears as infinite transcendence in relation to the one who confronts death as death.

This transcendence is the very presupposition outside of language by virtue of which language appears as language, language that encounters death as death, and since this death appears to mortals in its imminent uncertainty as advent of futurity, language therefore can never become self-enclosed autochthonous entity, but constantly points itself towards, goes ahead to the undecidability of the unknown advent of the inapparent. This transcendence which does not have a topos of its own can not be named, precisely because it is the event of naming itself.

\section{The Secret: the Name of Transcendence}

This gift of language always bears the mark of death. Søren Kierkegaard knew something of this: that the gift, which is the gift of death, is also thereby a singular experience of transcendence, an experience of the-there, which is 'death's decision', a trembling and a cry. This death's decision (Kierkegaard 1993, pp. 71-102), which gives "earnestness" to existence, which is the utmost existential interest of the singular being with a proper name, refuses to serve the interests of the universal Spirit; it is what does not belong to the ethical order of the system of visible forms. Its claim is then to be sought elsewhere, in that Archimedean point where language presents the un-presentable as discontinuous presentation, as dis-figuring, momentary 
advent, whose singularity of occurrence suspends the universal order of generality. Kierkegaard does not abandon language as insufficient to express the arrival of the divine, or, as merely expression of the universal ethical Spirit that dialectically constitutes the historical-speculative world. What is more interesting is Kierkegaard's recognition of language's insufficiency in relation to itself, the incommensurability between the singular eruption of the event of its coming and the universal claims of the Speculative history in its categorical claims to grasp the result of a becoming, which is the process of a universal history. Language that is marked by death's decision, (because death is what is un-presentable in the negative labor of a conceptual language) opens the very figuration of language to the un-presentable apparition of the inapparent, tearing language from itself in fear and trembling and giving over to its ruination. Neither this death's decision nor this language at the limit of cognition is communicable in the generality of the concept, or within the ethical realm of the universal where each particular is homogenous with others, exchangeable with others. As such, this language can only be indirect communication that bears - or can not bear - the mark of death's decision which refuses to belong to the universal ethical realm which is produced by the labor of negativity. Language neither presents itself as the self-presentation of the spirit of negativity, nor presents its absence. Language rather marks, remarks, demarks death's decision which renders language irreducible, incommensurable, noncontemporaneous to the ethical claims of a universal history. This language is not readable and decipherable in the universal Book, or system of the ethical without remainder. This remainder is what Kierkegaard calls secret.

If the indirect communication is marked by death's decision, it is because its incommensurable differentiating places, first of all, the one who speaks outside of all communication. As Kierkegaard knew, this alone enables transcendence to arrive, bursting out of closure of the immanence of self-presence, i. e., from the ethical realm of generality. This advent of transcendence is neither the plenitude of pure presence ( the parousia of the metaphysics of the Subject), nor the impoverishment that arises out of the need of the subject that needs to be nourished: it is rather the arrival as the fullness of time that at once darkens the presencing of presence with the excess of its brilliance. This darkness of light that suddenly makes its appearance is not the fusion unto transcendence but a differentiating transcendence, a holding-together-as-holding-apart. Therefore it does not work like Hegelian speculative judgment that bears its own dissolution within it, converting its own dissolution unto the unity of the concept or the Subject. Therefore unlike the speculative judgment of a speculative dialectic, this death's decision does 
not form historical-dialectical totalities, but mark this demonic, monstrous disjunctive co-figuration, which is the site of more originary historicity than speculative universal history. It bears the anguishing face of that originary melancholy that is touched by death's decision. It is the melancholic face of the singular this being who bears a proper name called Søren Kierkegaard, who bears 'thorn in the flesh', because - in so far he is - bears the decision of 'is not', which is death's decision.

Indirect communication is nothing negative, but rather it affirms what is outside the communicable entities of the given world. What, then, indirect communication affirms is the event of communication, that moment of eruption of pure communication, on the basis of which alone the singular individual, being first placed outside of all given modes of communication - that means being abandoned in the open - communicates with the transcendent arrival. That means, the mortal existent communicates and makes communication the essential of his existence by first of all being placed outside all communication, first of all being deprived or being excess of all communication. He names - for man is someone who is essentially name-giver - by first of all being placed outside the name, first of all being deprived of the name, or being excess of the name. One, whose essential being lies in communication, communicates by being placed outside all communication. One whose essential being lies in naming, names by being placed outside all the given names. He then derives communication from an essential non-communication and naming from an essential namelessness.

This essential solitude of language - of its non-communication and namelessness - renders language irreducible to any cognitive function of a categorial-logical thinking. This non-communication of communication, this ecstatic solitude, which for Kierkegaard is also, in this very manner, an intimation of transcendence, is the secret of language. Secret is not the interiority of an individual consciousness shut within itself, nor is it the treasure which the isolated self keeps it for itself as kernel of consciousness, shut from the divine and other mortals. It is rather the ecstatic solitude of language, bursting out of any self-enclosure unto an ecstatic transcendence, a non-communicating communication with the outside, the ecstatic relation to the event of coming which is not "the presently given entities", which does not yet exist in the already existing manner of communication. The language of naming, unlike the categorical language of judgment at its cognitive instrumentality, is ecstatic, because it ex-tatically ex-sists outside of the nameable. Secret is the name of transcendence, the event that is not yet of communication, which in order to affirm the arrival of the wholly otherwise, must step outside communication in ethical terms. Therefore Abraham keeps silent; he does not speak in ethical terms, for he has to offer, what is commanded him to offer, is the gift of death. The secret is the event of 
language itself that opens and yet withdraws from any self-presentation, and thus announcing the advent of the outside, which is the name of the pure future that belongs to the entirely heterogeneous order, completely incommensurable to the order of generality represented by the ethical, universal signification. If language itself is tied to an originary finitude, to its own ruination, it is in so far as this originary finitude is the very opening of language from any selfenclosure and self-presence, not at the same time in the name of an absence opposed to presence, but as oblique coming, as what Derrida (1995) calls "oblique offering". The completely heterogeneous order where the singularity of the mortal, with his irreducible suffering and anguish in the face of death is not evaded in the name of the generality of the ethical signification is the order where language which the singular mortal speaks must assume entirety different modality than the modality of signification. For Kierkegaard such an essential language, more originary than the language of signification, assumes a form of address, which is prayer addressed to the inapparent advent of the completely other, the transcendence itself. In the language of prayer alone the suffering mortal is open to the redemptive happiness arriving from a wholly otherwise destination, from an immemorial past and from an incalculable, pure future beyond the immanence of self-present now instants.

\section{References}

BENJAMIN, Walter. "On Language as Such and on the Language of Man". In Peter Demetz (ed.) \& Edmund Jephcott (trans.) Reflections, 314-332. New York : Schocken Books, 1986.

BENJAMIN, Walter. 'Über den Begriff der Geschichte'. In Illuminationen, 251-261. Frankfort: Sukhramp, 1977.

BLOCH, Ernst. The Spirit of Utopia . Trans. Anthony A. Nassar .Stanford: Stanford University Press, 2000.

BLOCH, Ernst. The Principle of Hope, Vol. 1. Trans. Neville Plaice, Stephen Plaice and Paul Knight .Cambridge\& Massachusetts: The MIT Press, 1995.

DERRIDA, Jacques. On the Name. Trans. David Wood, John P. Leavey and Ian McLeod . Stanford: Stanford University Press, 1995.

HALE, Geoffrey A. Kierkegaard and the Ends of Language. Minneapolis: University of Minnesota Press, 2002.

HEIDEGGER, Martin. Four Seminars . Trans. Andrew Mitchell and Francois Raffoul. Indiana: Indiana University Press, 2003.

HEIDEGGER, Martin. Ontology: The Hermenutics of Facticity . Trans. John van Buren. Indianapolis: Indiana University Press, 1999.

HEIDEGGER, Martin. "On of the Nature of Language". In Peter D. Hertz ( trans.) On the Way to Language. New York: Harper \& Row, 1982. 
HEIDEGGER, Martin. "Hölderlins Hymnen 'Germanien' und 'Der Rhein'”. In Gesamtausgabe, Band 39. Frankfurt: Vittorio Klostermann, 1980.

HEIDEGGER, Martin. Being and Time. Trans. John Macquarrie and Edward Robinson. New York: Harper and Row, 1962.

KIERKEGAARD, Søren. "At a Graveside" . In Howard V Hong and Edna Hong (trans.) Three Discourses on Imagined Occasions, 71-102. Princeton, NJ.: Princeton University Press, 1993.

LEVINAS, Emmanuel. God, Death and Time. Trans. Bettino Bergo. Stanford: Stanford University Press, 2000.

LEVINAS, Emmanuel. Time and the Other. Trans. Richard A Cohen. Pittsburgh\& Pennsylvania: Duquesne University Press, 1987.

ROSENZWEIG, Franz. The Star of Redemption .Trans. Barbara E. Galli . Wisconsin: The University of Wisconsin Press, 2005.

SCHELLING, F.W.J.von. The Ages of the World. Trans. Jason M. Wirth. Albany: State University of New York, 2000.

SCHELLING, F.W.J.von. Philosophical Inquiries into the Nature of Human Freedom, tr. James Gutmann ( La Salle: Illinois, 1936). 